\title{
Pengaruh Taraf Protein dan Lisin Ransum terhadap Pelemakan pada Ayam Kampung Umur 12 Minggu
}

\author{
The Effect of Protein Levels and L-Lysine Rations of Fatty Kampong Chicken in 12 Weeks
}

\author{
O. P. Ramdani, N. Suthama dan U. Atmomarsono
}

Fakultas Peternakan dan Pertanian Universitas Diponegoro, Semarang

Corresponding e-mail : putriramdani94@gmail.com

\begin{abstract}
This study aimed to determine the effect of different levels of protein rations with lysine supplementation in chicken so that protein can be utilized maximally in chickens aged 12 weeks. The materials used in this research were Chicken used is 240 chicken DOC (unsex) with average body weight $25.2 \pm 1.00 \mathrm{~g}$ (CV 3.97\%). The research design used was completely randomized factorial pattern $2 \times 3$. The main factor was the level of feed protein consisting of 2 levels $(17 \%$ and 14\%) second factor was the level of lysine addition consisting of 3 levels $(0.6 \% ; 0,7 \%$ and $0.8 \%)$. Parameters observed blood cholesterol, fat mass of meat. Data collection was done at 12 weeks or in the finisher. The data obtained were analyzed using variance analysis (ANOVA) and F test. The results showed that there was no interaction $(\mathrm{P}>0.05)$ between protein level in ration and lysine addition to blood cholesterol and meat fat mass. The conclusions of this study were the provision of protein levels and the addition of different lysine amino acids did not affect blood cholesterol and meat fat mass.
\end{abstract}

Key words: chicken, protein level, lysine, blood cholesterol, fat mass of meat

\begin{abstract}
ABSTRAK
Penelitian ini bertujuan mengetahui pengaruh taraf protein ransum berbeda dengan suplementasi lisin pada ayam kampung sehingga protein dapat dimanfaatkan dengan maksimal pada ayam umur 12 minggu. Materi yang digunakan penelitian ini adalah Ayam yang digunakan adalah 240 ekor DOC ayam kampung (unsex) dengan rata-rata bobot badan $25.2 \pm 1,00 \mathrm{~g}$ (CV 3.97\%). Rancangan penelitian yang digunakan acak lengkap (RAL) pola faktorial $2 \times 3$. Faktor utama adalah taraf protein ransum terdiri atas 2 taraf (17\% dan 14\%) faktor kedua adalah taraf penambahan lisin yang terdiri dari 3 taraf $(0.6 \% ; 0.7 \%$ dan $0.8 \%)$. Parameter yang diamati kolesterol darah, massa lemak daging. Pengambilan data dilakukan pada minggu ke 12 atau pada masa finisher. Data yang didapat dianalisis dengan menggunakan analisis ragam (ANOVA) dan uji F. Hasil penelitian menunjukkan bahwa tidak terdapat interaksi $(\mathrm{P}>0.05)$ antara taraf protein dalam ransum dan penamabahan lisin terhadap kolesterol darah dan massa lemak daging. Simpulan penelitian ini adalah pemberian taraf protein dan penambahan asam amino lisin yang berbeda tidak mempengaruhi kolesterol darah dan massa lemak daging.
\end{abstract}

Kata kunci : ayam kampung, taraf protein, lisin, kolesterol darah, massa lemak daging

\section{PENDAHULUAN}

Ayam kampung adalah unggas lokal asli Indonesia yang banyak dipelihara di daerah pedesaan, yang dimanfaatkan sebagai sebagai penghasil protein hewani berupa telur dan daging. Produk ayam kampung mempunyai kelebihan karena daging dan telur lebih disukai dan harga terjangkau oleh masyarakat konsumen. Namun, kelemahan yang dimiliki oleh ayam kampung yaitu produktivitas rendah dan pertumbuhan juga lambat.

Ransum merupakan faktor yang sangat mempengaruhi produktivitas ayam.
Penelitian ini dilakukan dalam upaya untuk meningkatan produktivitas ayam kampung. Upaya yang dapat dilakukan adalah perbaikan ransum melalui kualitas protein. Protein berkualitas baik memiliki asam amino dalam jumlah yang memadai dan seimbang. Apabila kekurangan asam amino esensial di dalam ransum akibatnya adalah pemanfaatan asam amino lainnya menjadi terganggu. Terganggunya pemanfaatan asam amino dapat menghambat pertumbuhan dan/atau penurunan produktivitas. 
Asam amino esensial tidak dapat disintesis oleh tubuh ternak khususnya umggas sehingga harus tersedia di dalam ransum. Asam amino lisinsebagai contoh, meskipun digunakan dalam ransum dalam jumlah sedikit teta[pi sanggat penting dalam keberhasilan pertumbuhan ayam (unggas). Oleh sebab itu, protein ransum rendah dikhawatirkan berakibat terjadinya kekurangan asupan asam amino, terutama lisin. Kandungan lisin sangat dibutuhkan oleh ayam untuk pertumbuhan kaitannya dengan proses metabolisme lemak dalam pembentukan daging yang baik dengan deposisi lemak rendah.

Keseimbangan nutrient ransum terutama, asam amino esensial yang dikonsumsi dapat mempengaruhi pertambahan bobot badan ayam. Pertambahan bobot badan yang ditunjang oleh rendahnya massa lemak daging merupakan ciri bahwa ayam memiliki produktivitas yang baik. Produktivitas yang baik menggambarkan bahwa protein yang dimanfaatkan dan didukung oleh perlemakan rendah pada ayam, berlangsung dengan baik. Berdasarkan permasalahan tersebut di atas maka dilakukan penelitian untuk mengevaluasi perbedaan protein ransum yang dikombinasi dengan penambahan lisin terhadap kemampuan perlemakan pada ayam kampung.

Tujuan penelitian adalah untuk mengetahui pengaruh kadar protein ransum berbeda dengan suplementasi lisin pada ayam kampung sehingga protein dapat dimanfaatkan dengan maksimal disatu sisi, dan lemak minimal sehingga menghasilkan pertumbuhan yang seimbang dari segi kualitas pada ayam umur 12 minggu. Manfaat hasil penelitian adalah memperoleh formulasi ransum dengan minimal ditambah lisin dapat menghasilkan pertumbuhan ayam kampung yang baik dilihat dari perbandingan deposisi protein dan deposisi lemak.

\section{MATERI DAN METODE}

Penelitian ini dilaksanakan di Kandang Laboraturium Produksi Ternak
Unggas Fakultas Peternakan dan Pertanian Universitas Diponegoro. Analisis proksimat terhadap bahan pakan dan ransum dilakukan di Laboraturium Ilmu Nutrisi Makanan Ternak Fakultas Peternakan dan Pertanian Universitas Diponegoro. Analisis kandungan asam amino ransum dilakukan di Laboraturium Terpadu Institut Pertanian Bogor.

Ayam yang digunakan adalah 240 ekor DOC ayam kampung (unsex) dengan rata-rata bobot badan $25,2 \pm 1,00 \mathrm{~g}$ (CV $3,97 \%$ ) dipelihara selama 12 minggu, perlakuan dimulai sejak umur 1 hari. kandang yang digunakan bertipe wire floor sebanyak 24 unit percobaan. Tiap unit percobaan diisi 10 ekor ayam.

Bahan pakan yang digunakan adalah jagung, bekatul, bungkil kedelai, tepung ikan, minyak nabati, $\mathrm{CaCO}_{3}$, DL-metionin, L-lisin HCL, premiks vitamin dan mineral. Analisis proksimat terhadap bahan pakan dan ransum dilakukan di Laboraturium Ilmu Nutrisi Makanan Ternak Fakultas Peternakan dan Pertanian Universitas Diponegoro. Analisis kandungan asam amino ransum dilakukan di Laboraturium Terpadu Institut Pertanian Bogor. Pola ransum adalah single stage, yaitu hanya satu macam ransum untuk pemeliharaan selama 12 minggu. Pakan dan air minum diberikan ad libitum.

Kandang yang digunakan adalah kandang kelompok dengan lantai wire untuk pemeliharaan dan kandang baterai untuk total koleksi eksreta. Brooder yang digunakan adalah 1 lampu bohlam berdaya 60 watt. Tempat pakan berupa trough dari bamboo. Tempat minum trough sampai umur 4 minggu selanjutnya menggunakan bell drinker.

\section{Rancangan Penelitian}

Penelitian ini menggunakan rancangan acak lengkap (RAL) pola faktorial $2 \times 3$. Faktor utama adalah taraf protein ransum terdiri atas 2 taraf $(17 \%$ dan $14 \%)$ factor kedua adalah taraf penambahan lisin yang terdiri dari 3 taraf $(0,6 \% ; 0,7 \%$ dan $0,8 \%)$. Komposisi ransum tertera dalam Tabel 1. 
Tabel 1. Komposisi ransum

\begin{tabular}{|c|c|c|c|c|c|c|}
\hline \multirow[b]{2}{*}{ Bahan Pakan } & \multicolumn{6}{|c|}{ Komposisi } \\
\hline & P1L1 & P1L2 & P1L3 & P2L1 & P2L2 & P2L3 \\
\hline & \multicolumn{6}{|c|}{ - } \\
\hline Jagung & 50,00 & 50,00 & 50,00 & 52,50 & 52,50 & 52,50 \\
\hline Bekatul & 23,00 & 23,00 & 23,00 & 26,50 & 26,50 & 26,50 \\
\hline Tepung ikan & 10,00 & 10,00 & 10,00 & 8,00 & 8,00 & 8,00 \\
\hline Bungkil kedelai & 12,30 & 12,30 & 12,30 & 8,00 & 8,00 & 8,00 \\
\hline Minyak nabati & 2,00 & 2,00 & 2,00 & 2,00 & 2,00 & 2,00 \\
\hline L-lisin $\mathrm{HCl}$ & 0,60 & 0,70 & 0,80 & 0,60 & 0,70 & 0,80 \\
\hline Premiks & 1,00 & 1,00 & 1,00 & 1,00 & 1,00 & 1,00 \\
\hline $\mathrm{CaCO}_{3}$ & 1,70 & 1,70 & 1,70 & 2,00 & 2,00 & 2,00 \\
\hline DL-metionin & 0,40 & 0,40 & 0,40 & 0,50 & 0,50 & 0,50 \\
\hline Total & 101,00 & 101,10 & 101,20 & 101,10 & 101,20 & 101,30 \\
\hline \multicolumn{7}{|c|}{ Kandungan Nutrien } \\
\hline EM (kkal/kg) & $2.823,62$ & $2.820,80$ & $2.817,99$ & $2.825,75$ & $2.822,93$ & $2.820,12$ \\
\hline PK & 17,10 & 17,08 & 17,07 & 14,69 & 14,68 & 14,66 \\
\hline SK & 5,01 & 5,01 & 5,00 & 4,99 & 4,98 & 4,98 \\
\hline LK & 8,16 & 8,15 & 8,14 & 8,06 & 8,06 & 8,05 \\
\hline $\mathrm{Ca}$ & 0,92 & 0,92 & 0,92 & 0,94 & 0,94 & 0,94 \\
\hline $\mathrm{P}$ & 0,46 & 0,46 & 0,46 & 0,47 & 0,47 & 0,47 \\
\hline Lisin & 1,17 & 1,27 & 1,37 & 1,08 & 1,18 & 1,28 \\
\hline Metionin & 0,60 & 0,60 & 0,60 & 0,64 & 0,64 & 0,64 \\
\hline Arginin ( & 0,90 & 0,90 & 0,90 & 0,64 & 0,64 & 0,64 \\
\hline Lisin (mg) & 68,42 & 74,36 & 80,26 & 73,52 & 80,38 & 87,31 \\
\hline \multicolumn{7}{|l|}{ Protein (g) } \\
\hline Lisin : arginin & $1,30: 1$ & $1,41: 1$ & $1,52: 1$ & $1,69: 1$ & $1,84: 1$ & $2,00: 1$ \\
\hline Protein : EM & $1: 165$ & $1: 165$ & $1: 165$ & $1: 192$ & $1: 192$ & $1: 192$ \\
\hline Lisin : EM & $1: 263,3$ & $1: 263,3$ & $1: 222,49$ & $1: 311,3$ & $1: 311,29$ & $1: 255,83$ \\
\hline
\end{tabular}

Keterangan :

EM dihitung dari 72\% GE (Gross Energy) menurut Schaible (1979)

Kadar PK dan SK diperoleh dari hasil analisis proksimat

Kadar Ca dan P diperoleh dari hasil analisis AAS

Kadar asam amino bahan pakan ditentukan menurut Hartadi et al. (1980)

Kombinasi perlakuan yang dilakukan adalah sebagai berikut :

P1L1 : pakan dengan taraf protein $17 \%$ dan penambahan lisin $0,6 \%$ dari ransum

P1L2 : pakan dengan taraf protein $17 \%$ dan penambahan lisin $0,7 \%$ dari ransum

P1L3 : pakan dengan taraf protein $17 \%$ dan penambahan lisin $0,8 \%$ dari ransum

P2L1 : pakan dengan taraf protein $14 \%$ dan penambahan lisin $0,6 \%$ dari ransum

P2L2 : pakan dengan taraf protein $14 \%$ dan penambahan lisin $0,7 \%$ dari ransum

P2L3 : pakan dengan taraf protein $14 \%$ dan penambahan lisin $0,8 \%$ dari ransum

Tahap persiapan penelitian ada 2 macam, yaitu persiapan umum dan persiapan teknis. Persiapan umum meliputi pembuatan proposal, survei tempat, ternak dan bahan pakan, analisis proksimat bahan pakan dan formulasi ransum dan analisis kandungan asam amino ransum. Persiapan teknis meliputi persiapan kandang, persiapan cage, pembuatan pakan, persiapan ternak, dan alatalat pendukung yang akan digunakan dalam penelitian. Tahap perlakuan akan dilaksanakan selama 12 minggu pemeliharaan.

Pengambilan data kadar kolesterol darah dilakukan pada periode finisher. Sebanyak 1 ekor ayam dari tiap ulangan dipilih secara acak untuk diambil darahnya. Darah diambil pada bagian jantung menggunakan disposable syringe ukuran 3 ml. Darah dimasukkan ke dalam tabung 
phlebotomi dan ditempatkan dalam boks es sampai siap dianalisis.

Bobot ayam ditimbang sebelum disembelih, lalu dilakukan pencabutan bulu, setelah itu dilakukan pengeluaran viscera (jeroan), dan setelah menjadi karkas (tanpa jeroan, kepala dan cakar) daging dan tulang dipisahkan, masing-masing ditimbang. Sampel daging dada sebanyak 20 gram dibungkus kertas aluminium foil, ditempatkan dalam termos es, kemudian dianalisis kandungan lemaknya dengan Metode Mikro Kjeldahl.

\section{Parameter Penelitian}

Parameter yang diamati dalam penelitian ini adalah :

1. Kadar kolesterol darah, dilakukan dengan pengambilan darah yang dilakukan pada minggu ke-12, setelah pemuasaan dan sebelum pemotongan. Sampel darah di ambil dari jantung menggunakan spuit $3 \mathrm{ml}$ lalu darah di masukkan kedalam tabung phlebotomy, selanjutnya didiamkan sampai cairan darah memisah menjadi serum, kemudian pengukuran kadar kolesterol pada serum darah dilakukkan dengan metode enzymatis.

2. Massa lemak daging, diperoleh dari analisis kadar lemak daging pada saat ayam berumur 12 minggu. Massa lemak daging $=$ lemak daging dada dan paha segar (\%) x bobot daging $(\mathrm{g})$.

\section{Analisis Statistik}

Model linier aditif pada faktorial yang diterapkan pada minggu ke-1 sampai 12 yaitu:

$$
\begin{aligned}
& Y_{\mathrm{ij}}=\mu+\alpha_{\mathrm{i}}+\beta_{\mathrm{j}}+(\alpha \beta)_{\mathrm{ij}}+\varepsilon_{\mathrm{ijk}} \\
& ; \mathrm{i}=(1,2) \\
& ; \mathrm{j}=(1,2,3) ; \mathrm{k}=(1,2,3,4)
\end{aligned}
$$

Keterangan :

$\mathrm{Y}_{\mathrm{ij}}=$ Nilai pengamatan pada kombinasi perlakuan taraf PK ke-i dan taraf lisin ke-j pada ulangan ke-k
$\mathrm{M}=$ Nilai rata-rata umum perlakuan

$\alpha_{\mathrm{i}}=$ Pengaruh aditif dari perlakuan taraf PK ke-i

$\beta_{\mathrm{j}}=$ Pengaruh aditif dari perlakuan taraf lisin ke-j

$(\alpha \beta)_{\mathrm{ij}}=$ Pengaruh aditif dari kombinasi perlakuan taraf PK ke-i dan taraf lisin ke-j

$\varepsilon_{\mathrm{ijk}}=$ Pengaruh galat percobaan

Hipotesis statistika dari penelitian ini yaitu:

a. $\mathrm{H} 0=(\alpha \beta)_{\mathrm{ij}}=0$ : Tidak ada perbedaan pengaruh kombinasi perlakuan taraf protein dan lisin ransum terhadap variabel yang diamati.

$\mathrm{H} 1=(\alpha \beta)_{\mathrm{ij}} \neq 0:$ Paling tidak ada satu kombinasi perlakuan taraf protein dan lisin ransum yang memberikan pengaruh terhadap variabel yang diamati.

b. $\mathrm{H} 0=\alpha_{i}=0$ : Tidak ada perbedaan pengaruh perlakuan taraf protein ransum terhadap variabel yang diamati.

$\mathrm{H} 1=\alpha_{\mathrm{i}} \neq 0$ : Paling tidak ada satu perlakuan taraf protein ransum yang memberikan pengaruh terhadap variabel yang diamati.

c. $\mathrm{HO}=\beta_{\mathrm{j}}=0$ : Tidak ada perbedaan pengaruh perlakuan taraf lisin terhadap variabel yang diamati.

$\mathrm{H} 1=\beta_{\mathrm{j}} \neq 0$ : Paling tidak ada satu perlakuan taraf lisin yang memberikan pengaruh terhadap variabel yang diamati.

Data dianalisis menggunakan uji $\mathrm{F}$, kriteria pengujian adalah sebagai berikut :

Jika $\mathrm{F}$ hit $<\mathrm{F}$ tabel, maka H0 diterima dan H1 ditolak

Jika $\mathrm{F}$ hit $\geq \mathrm{F}$ tabel, maka $\mathrm{H} 1$ diterima dan $\mathrm{HO}$ ditolak 


\section{HASIL DAN PEMBAHASAN}

\section{Kadar Kolesterol Darah}

Pengaruh pemberian taraf protein dan lisinterhadap kadar kolesterol darah terdapat pada Tabel 2. Berdasarkan analisis bahwa pemberian level protein dan penambahan lisin dalam ransum tidak menunjukkan perbedaan yang nyata $(\mathrm{P}>0,05)$ terhadap kadar kolesterol darah ayam kampung umur 12 minggu.

Berdasarkan hasil penelitian rata-rata taraf protein ransum 17\% sebesar 142,08 $\mathrm{mg} / \mathrm{dl}$ dan taraf protein ransum 14\% sebesar $147,68 \mathrm{mg} / \mathrm{dl}$. Hasil ini lebih rendah dari penelitian Suryo, (2012) bahwa kadar kolesterol darah ayam kampung yaitu $163,53 \mathrm{mg} / \mathrm{dl}$. Kadar kolesterol darah ayam kampung adalah 52-148 mg/dl (Basmacioglu dan Ergul, 2005). Menurut Swenson (1984) nebyatakan bahwa total kolesterol sel darah unggas antara 125-200 $\mathrm{mg} / \mathrm{dl}$. Dalam penelitian ini hasil yang didapat menujukkan kisaran normal kadar kolesterol ayam kampung yang dipelihara dalam 12 minggu.

Ayam kampung tergolong dengan produktivitasnya yang lambat sehingga memiliki kandungan lemak yang rendah. Lemak yang tinggi dalam tubuh akan mengakibatkan terjadinya kenaikan kadar
LDL yaitu lipoprotein yang kaya akan kolesterol (Muhajir 2002). Semakin banyak lemak yang dikeluarkan oleh tubuh, dengan demikian kadar kolesterol dalam tubuh akan menurun (Syahruddin 2002).

Kolesterol didalam tubuh berasal dari dua sumber, yaitu dari makanan (kolesterol eksogen) dan sintesis di dalam tubuh (kolesterol endogen) ( Muchtadi et al., 1993).

\section{Massa Lemak Daging}

Pengaruh pemberian taraf protein dan lisinterhadap massa lemak daging terdapat pada Tabel 3. Berdasarkan analisis bahwa pemberian level protein dan penambahan lisin dalam ransum tidak menunjukkan perbedaan yang nyata $(\mathrm{P}>0,05)$ terhadap massa lemak daging ayam kampung umur 12 minggu.

Lemak tubuh termasuk lemak dalam daging tidak berpengaruh nyata, meskipun secara statistik angka tidak nyata namun secara numerik angka mengalami perbedaan.Lemak dalam tubuh dapat di pengaruhi oleh banyaknya asupan makanan yang mengandung protein dan energi yang dikonsumsi. Tidak adanya interaksi antara taraf protein dan penambahan lisin disebabkan karena bobot hidup dan massa daging tidak berbeda nyata.

Tabel 2. Pengaruh perlakuan terhadap kadar kolesterol darah ayam kampung

\begin{tabular}{llll}
\hline \multirow{2}{*}{$\begin{array}{l}\text { Penambahan } \\
\text { Lisin }\end{array}$} & \multicolumn{2}{l}{ Taraf Protein Ransum } & Rata-rata \\
\cline { 2 - 3 } -----------\%--------- & P1 (17\%) & P2 (14\%) \\
L1 $(0,6 \%)$ & 130,53 & 140,20 & 125,36 \\
L2 $(0,7 \%)$ & 148,45 & 138,60 & 143,52 \\
L3 $(0,8 \%)$ & 147,27 & 164,24 & 155,75 \\
\hline Rata-rata & 142,08 & 147,68 & 144,88 \\
\hline
\end{tabular}

Tabel 3. Pengaruh perlakuan terhadap massa lemak daging ayam kampung

\begin{tabular}{|c|c|c|c|}
\hline \multirow{2}{*}{$\begin{array}{l}\text { Penambahan } \\
\text { Lisin }\end{array}$} & \multicolumn{2}{|c|}{ Taraf protein ransum } & \multirow[t]{2}{*}{ Rata-rata } \\
\hline & P1 $(17 \%)$ & $\mathrm{P} 2(14 \%)$ & \\
\hline \multicolumn{4}{|c|}{ 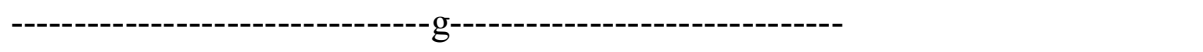 } \\
\hline L1 $(0,6 \%)$ & 3,65 & 4,21 & 3,93 \\
\hline $\mathrm{L} 2(0,7 \%)$ & 3,38 & 4,63 & 4,01 \\
\hline L3 $(0,8 \%)$ & 4,25 & 3,68 & 3,97 \\
\hline Rata-rata & 3,76 & 4,17 & 3,96 \\
\hline
\end{tabular}


Bobot hidup dan massa daging tidak dipengaruhi oleh interaksi antara taraf protein dan penambahan lisin ransum, seperti hasil penelitian Quentin et al. (2005) pada ayam broiler umur 42 hari. Salah satu cara mengurangi perlemakan adalah dengan jalan mevariasikan dengan nutrient pakan, terutama energi protein. Peningkatan energi pakan akan meningkatkan kandungan lemak abdominal (Wahju, 2004).

Hasil ini lebih rendah dari penelitian Cholis et al. (2014), bahwa massa lemak daging ayam kampung tertinggi adalah 12,47 g. Seekor ternak mengkonsumsi energi melebihi kebutuhan untuk pemeliharaan tubuh pada kondisi lingkungan yang menguntungkan, maka dapat diharapkan bahwa ternak tersebut akan menimbun energi sebagai lemak dalam tubuhnya. Lemak yang terdapat dalam tubuh ternak berasal dari lemak, karbohidrat dan protein dalam pakan. Karbohidrat, protein dan sebagian lemak pakan yang telah dicerna dan di absorbsi masuk tubuh bila sampai kelebihan akan diubah menjadi lemak dan disimpan sebagai lemak tubuh (Sumodiningrat, 1999).

Faktor penambahan lisin dan faktor taraf protein ransum tidak berpengaruh nyata $(\mathrm{P}>0,05)$ terhadap massa lemak daging karena konsumsi lisin tidak berbeda. Terlihat pada taraf protein rendah $14 \%$ dan taraf penambahan lisin tertinggi $0,7 \%$ di dapatkan hasil yang tinggi dibandingkan dengan taraf protein ransum dan taraf penambahan lisin lainnya yaitu $4,63 \%$. Semakin tinggi energi pakan yang di konsumsi menyebabkan kandungan lemak daging tinggi, apabila ayam mengkonsumsi energi berlebihan maka ayam akan menimbun energi tersebut dalam bentuk lemak. Wahju (1992) menyatakan bahwa apabila ransum kekuranagn protein atau bagian asam amino esensial akan menyebabkan penurunan produksi dan ayam akan kehilangan berat badan. Sebaliknya kelebihan protein atau asam amino dalam ransum dapat menyebabkan penurunan pertumbuhan serta kandungan lemak dan asam urat darah.

\section{KESIMPULAN}

Pemberian taraf protein dan penambahan asam amino lisin yang berbeda tidak memberikan pengarh terhadap kolesterol darah dan massa lemak daging.

\section{DAFTAR PUSTAKA}

Anggorodi. 1995. Nutrisi Aneka Ternak Unggas Cetakan Ke-1. Penerbit PT Gramedia, Jakarta.

Basmacioglu, H. and M. Ergul. 2005. Research on the factor affecting cholesterol content and some other characteristics of eggs in laying hens. Turkey. J. Vet. Anim. Sci. 29:157-164.

Cholis, M. A., E. Suprijatna dan N. Suthama. 2014. Kecernaan lemak dan massa lemak daging pada ayam kampung persilangan yang mendapat ransum penambahan umbi bunga dahlia sebagai sumber inulin. J. Animal Agriculture. 3 (2) : 204-210.

Sumodiningrat, G. 1999. Pemberdayaan Masyarakat dan Jaringan Pengaman Sosial, Jakrta: PT Gramedia Pustaka Utama.

Muchtadi, D., N. S. Palupi dan M. Astawan. 1993. Metabolisme Zat Gizi: Sumber, Fungsi dan Kebutuhan Bagi Tubuh Manusia. Jilid II. Pustaka Sinar Harapan: Jakarta.

Muhajir. 2002. Turunkan kolesterol ayam kampung dengan lisin. Poultry Indonesia.Ed. September. 68-69.

Soeparno, 1994, Ilmu dan Teknologi Daging, Gadjah Mada University Press, Yogyakarta.

Suryo, H., T. Yudiarti dan Isroli. 2012. Pengaruh pemberian prebiotik sebagai aditif pakan terhadap kolesterol, high density lipoprotein (HDL) dan low density lipoprotein (LDL) dalam darah 
ayam kampung. J. Animal Agricalture. 1(2): 228-237.

Swenson, M. J. 1984. Phisiology properties and cellular and chemical constituent of blood. In Swenson, M. J. (Ed). Duke's Physiology of Domestic Animals. 10th Edition. Cornell University Press. Ithaca and London.

Syahruddin, E. 2001. Penambahan lisin pada protein rendah dalam ransum serta umur ternak terhadap kandungan lemak dan kolesterol karkas broiler. Andalas J. 13 (35): 92-98.

Wahju, J. 1992. Ilmu nutrisi unggas. Gadjah Mada University Press, Yogyakarta.

Wahju, J. 2004. Ilmu Nutrisi Unggas. Cetakan Kelima. Gadjah Mada University.Press. Yogyakarta. 